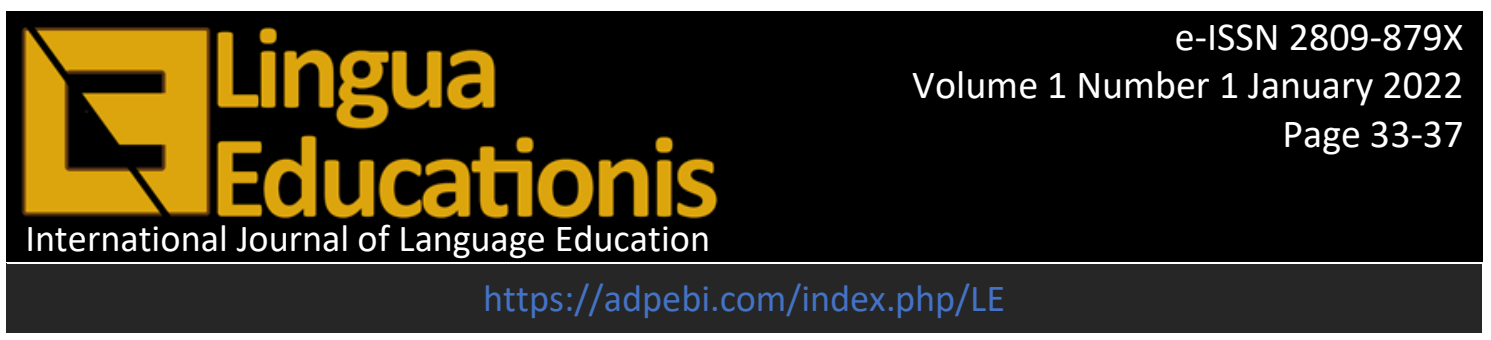

\title{
The Value of Character in The Song "Ilir-Ilir" by Sunan Kalijaga
}

\author{
Puji Anto' ${ }^{1}$ Fauzi Rahman², Tri Anita ${ }^{3}$ \\ Universitas Indraprasta PGRI, Jakarta, Indonesia \\ antopujifafafa@gmail.com ${ }^{1}$, itatrianita18@gmail.com²
}

Diserahkan: 10-12-2021 Direviu: 05-01-2022 $\quad$ Diterima: 15-12-2022 $\quad$ Diterbitkan: 31-01-2022

\begin{abstract}
This study focuses on the analysis of character values in the song "Ilir-Ilir" by Sunan Kalijaga. The research method is qualitative with a content analysis approach and uses paraphrasing techniques to interpret poetry or songs. The analysis of the lyrics of the song "Ilir-Ilir" produces several character values, namely introspective, noble, lofty ideals, useful, effort, hardworking, thorough, able to distinguish, thorough, don't waste time, sociable, and fast.
\end{abstract}

Keywords: Character Value; Ilir-Ilir, Sunan Kalijaga

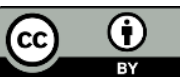

This work is licensed under a Creative Commons Attribution 4.0 International License.

\section{Introduction}

Culture is born and develops in society. Culture is a reflection of social activities that are passed down from generation to generation in society. Therefore, the process of the birth of culture cannot be separated from the values that have become an agreement in the community group. Cultural development cannot be separated from the creative process that arises from social actors. This development cannot be separated from sublimation which is influenced by the community for its ability to absorb all information around it. It is possible, a new civilization will degrade the old civilization (ancient or old school). Finally, there will be a process of cultural interference. Of course, it depends on the community's commitment to maintain the values that have been previously agreed upon. Do not close your eyes, that there needs to be an adjustment of a value to the context. Considerations for the adjustments that will be made sometimes go too far so that they tend to leave the values that have been imprinted and become life guidelines. The process of changing values in culture will certainly affect the behavior of its people. Behavior that is carried out continuously and becomes a habit will form a character. Of course, if there is a discrepancy between the previous values and the adjustment values, then what appears is behavior and becomes a deviant character. These deviations are happening in the current era. The number of cultures that enter in the end drowns out other cultures. In the end, emerging behaviors or community characters that come out of the intrinsic value of the culture itself. Therefore, it is necessary to introduce previous 
cultural values to restore these essential values. Cultural studies that are considered old are needed and reintroduce the values contained in them. There are many cultures in Indonesia. Therefore, cultural studies must slowly but surely be brought up, not necessarily centricity that is prioritized, but a sense of responsibility from each cultural actor to fix the direction of people's lives that have been eroded by the times.

The majority of Indonesia's population is Muslim. Therefore, society cannot be separated from the history of Islam in Indonesia itself. The spread of Islam in Indonesia was very successful. Islam can be accepted by the community well, this is evidenced by the number of adherents of the religion. The good reception could not be separated from the strategy or approach taken by the preachers who existed at that time. Wali Songo is a collection of Islamic preachers in Indonesia who have an important role in the acceptance of this belief, especially in Java. Wali Songo juxtaposed the rules in Islam with the culture that existed in society at that time. One of the da'wah strategies carried out is by creating songs or songs. By incorporating Islamic values in the song, this is the first step to spread Islamic values verbally. One example of a familiar song is "Ilir-Ilir", composed by Sunan Kalijaga, one of the Wali Songo. There are so many character values contained in the song array. Therefore, to answer the challenges of the times over the rush of culture from outside, of course negative culture, then this is one way to restore essential values to a culture that is starting to fade.

\section{Methods}

This research is a descriptive qualitative research type. The approach used is content analysis or content analysis. Bungin in Iswahyuningtyas said that the content analysis method is a research technique to make inferences that can be imitated (replicable) and data validity by taking into account the context. Content analysis deals with communication or the content of communication. The data in this study are in the form of secondary data obtained from journal articles. The data collection technique used is listen and note. Data validity uses data triangulation, namely checking the correctness of data by using comparisons between data from one data source and another data source. (Iswahyuningtyas, 2012).

Aminudin in Nuratni et al. said that there are various methods that can help interpret a poem or song (Tembang is a poem that is sung and is synonymous with Javanese ethnicity), one of which is the paraphrasing method. Paraphrasing means to describe in one's own words. Paraphrasing is a strategy for understanding the content of meaning by re-expressing the idea with different expressions from the author (Nuratni et al., 2014).

\section{Result}

\begin{tabular}{|l|l|}
\hline \multicolumn{1}{|c|}{ Larik } & \multicolumn{1}{|c|}{ Nilai Karakter } \\
\hline \multirow{2}{*}{ Lir-ilir, lir-ilir, tandure wus sumilir } & mawas diri \\
\cline { 2 - 2 } $\begin{array}{l}\text { tak ijo royo-royo, tak sengguh temanten } \\
\text { anyar }\end{array}$ & mulia \\
\hline \multirow{2}{*}{$\begin{array}{l}\text { Cah angon, cah angon, penekno blimbing yang luhur } \\
\text { kuwi, lunyu-lunyu penekno, kanggo } \\
\text { mbasuh dodotiro }\end{array}$} & bermanfaat \\
\cline { 2 - 2 } & usaha \\
\cline { 2 - 2 } & pekerja keras \\
\cline { 2 - 2 } & saksama \\
\hline
\end{tabular}




\begin{tabular}{|l|l|}
\hline $\begin{array}{l}\text { Dodotiro-dodotiro, kumitir bedah ing } \\
\text { pinggire }\end{array}$ & mampu membedakan \\
\hline $\begin{array}{l}\text { Dondomono jlumatono, kanggo sebo } \\
\text { mengko sore }\end{array}$ & teliti \\
\hline Mumpung padhang rembulane & jangan menyia-nyiakan waktu \\
\hline mumpung jembar kalangane & supel \\
\hline Yo surako surak Iyo & cepat \\
\hline
\end{tabular}

\section{Discussion}

According to the Big Indonesian Dictionary, character is psychological, moral or character traits that distinguish one person from another (Badan Pengembangan dan Pembinaan Bahasa, 2016). According to Thomas Lickona, character is an inner character that can be relied on and used to respond to various situations in a moral way. In addition, character can also be considered as the values of human behavior related to God Almighty, oneself, fellow humans, the environment, and nationality which are manifested in thoughts, attitudes, feelings, words and actions based on religious norms, laws and regulations., manners, culture, customs and aesthetics (Lickona, 2013). Based on some of these opinions, character is an attitude that distinguishes one human from another, both in dealing with God and the environment.

The song "Ilir-Ilir" is a song composed by Sunan Kalijaga in the XV-XVI centuries AD to preach. The process of creating this song was motivated by the need to spread the religion of Islam. Syiar means glory. Syiar means the process of conveying the glory of God to the audience. Not only conveying, but in it there is a teaching and learning process. Therefore, this analysis will be related to the world of education. The following is the poem "Ilir-ilir" by Sunan Kalijaga.

\section{Ilir-ilir}

Lir-ilir, lir-ilir,

tandure wus sumilir.

Tak ijo royo-royo,

tak sengguh temanten anyar.

Cah angon, cah angon, penekno blimbing kuwi, lunyu-lunyu penekno, kanggo mbasuh dodotiro.

Dodotiro-dodotiro,

kumitir bedah ing pinggire.

Dondomono jlumatono,

kanggo sebo mengko sore.

Mumpung padhang rembulane, mumpung jembar kalangane.

Yo surako surak Iyo. (Pujiharti, 2016) 
"Lir-ilir, lir-ilir, tandure wus sumilir." "Lir-ilir, lir-ilir" in Javanese means nglilir in other words wake up, "Lir-ilir, lir-ilir" 'ngun-bangun, ngun-bangun'. In the first line this can be translated that there is a call to wake up or wake up. Awareness is the key to getting better. Without awareness, what arises is arrogance. Always aware, selfintrospection, introspection to shortcomings are attitudes that not all humans have. "tandure wus sumilir" means the plant is already blooming. This array can be interpreted that there is a development process. If it is associated with attitude, it can be interpreted that as a human being must always grow and develop or want to be better or noble. If these meanings are combined, it means awareness to strive for self-improvement. This is in accordance with the essence of the word education, namely the process of changing attitudes and behavior of a person or several people.

"tak ijo royo-royo, tak sengguh temanten anyar", "tak ijo royo-royo" it can be interpreted that the dominant color is green. If likened to the condition of the plant, green signifies a healthy plant. It can be said that what is done must be successful. The character value reflected in this array is the existence of a noble or extraordinary goal. "tak sengguh temanten anyar" means like newlyweds. Being a newlywed, implied is a happiness. So, do everything happily to meet new hope. New hope is implied from the phrase "newlyweds" which means a commitment to live life. If it is linked back to the world of education, the teaching and learning process must be carried out happily for success. The character values contained in this array are always happy in living life, especially in studying.

"Cah angon, cah angon, penekno blimbing kuwi, lunyu-lunyu penekno, kanggo mbasuh dodotiro", "cah angon" can be interpreted as shepherd or caretaker. Because using the word "cah", means children or considered young. Array "cah angon" it can be interpreted to get used to it from small to be a person who always brings benefits to the environment, useful. Array "penekno blimbing kuwi" literally means climb the star fruit. Climbing means an effort, star fruit is a fruit, fruit can be interpreted as a goodness. The message implied in the line is an attempt to seek goodness. Array "lunyu-lunyu penekno" in Indonesian it means slippery, keep getting it. Slippery, means there are obstacles to take something. Whatever the obstacles must be taken. The meaning that emerges from the array is hard worker. "kanggo mbasuh dodotiro" means to wash or wash clothes. Washing or washing clothes in question is cleaning what has been used before. Clothing can be interpreted as knowledge. Cleaned can be interpreted with an understanding of inaccurate knowledge. So, it takes a deep thought to understand a knowledge, so that there are no mistakes, in other words carefully.

"Dodotiro-dodotiro, kumitir bedah ing pinggire.", means that the clothes that have been worn so far have been damaged. The knowledge that exists so far is in some ways a mistake. The attitude that is reflected in the array is being able to distinguish good and bad knowledge. This attitude is important to do when in a social or social relationship. It is undeniable, the environment presents very diverse things, both bad and good. Don't learn things related to invalid knowledge. Therefore, in the next line it reads "Dondomono jlumatono, kanggo sebo mengko sore.", which means sewing and grooming, to face later in the afternoon. False knowledge must be corrected and maintained as best as possible. This knowledge is a provision for old age. The attitude of character in this array is conscientious.

"Mumpung padhang rembulane", as long as there is a clear path. There is still an opportunity to explore this knowledge. Don't waste the opportunity. Speaking of the moon, it is related to time. The attitude reflected in this array is don't waste time. 
"mumpung jembar kalangane.", can be interpreted that there is a wide area. The place in question is the availability of facilities to draw, explore, and seek knowledge. The attitude that needs to be imitated from this array is to behave sociable with various kinds of knowledge. "Yo surako surak Iyo", the array can be interpreted immediately done. Iyo literally means yes. In other words, agree with what has been said above and immediately do it. Seek knowledge, while there is still a chance, then hurry up, seeking knowledge does not need to be delayed. What is implied in the array is fast in studying.

\section{Conclusion}

Based on the analysis and discussion above, it can be concluded that there are several character values that are reflected in the song "Ilir-ilir" by Sunan Kalijaga. The character values reflected are introspective, noble, lofty ideals, useful, effort, hardworking, thorough, able to distinguish, thorough, do not waste time, sociable, and fast. These character values are behaviors or attitudes, if cultivated in the context of education, they will be able to provide the best results, both in the process and in the results.

\section{References}

Badan Pengembangan dan Pembinaan Bahasa. (2016). Kamus Besar Bahasa Indonesia. Badan Pengembangan dan Pembinaan Bahasa, Kementerian Pendidikan dan Kebudayaan Republik Indonesia. https://kbbi.kemdikbud.go.id/

Iswahyuningtyas, F. (2012). Nilai-Nilai Pendidikan Karakter Pada Materi Ajar Bahasa Indonesia Kelas 2 SD Terbitan Tiga Serangkai. Digital Times. http://eprints.ums.ac.id/21096/25/Jurnal_Penelitian.pdf

Lickona, T. (2013). Pendidikan Karakter: Panduan Lengkap Mendidik Siswa Menjadi Pintar dan Baik (S. Lita (ed.); Terjemahan). Nusa Media.

Nuratni, N. K. R., Artawan, G., \& Sutresna, I. B. (2014). "Kajian Puisi Akrostik dengan Pendekatan Parafrasa untuk Meningkatkan Kemampuan Memahami Puisi Siswa Kelas VII.C di SMP Negeri 7 Singaraja." Undiksha, 2(1), 1-11. https://ejournal.undiksha.ac.id/index.php/JJPBS/article/view/3407

Pujiharti, E. S. (2016). Tembang “ Lir-Ilir” Bagi Guru Guna Menumbuhkan Motivasi Belajar di Pendidikan Formal (Studi Kasus di TK Wahid Hasyim Dinoyo Malang). Jurnal MPI, 1(2), 173-183. ejournal.uinmalang.ac.id/index.php/jmpi/article/download/3963/5492 